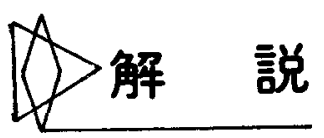

\title{
光の反射を利用した電極界面の in situ 計測法
}

\section{高村 \\ 1 緒言 \\ 2 手法の分類}

勉*

表面物理学における最近の進歩は目党むしく，量子論 をもとにして界面状態の記述が多数試みられる一方，多 くの新鋭観測手段により分子レ心゙ルでの新知見が続々え られている.観測手段としては, LEED, ESCA, Auger, INS 等などがあり，これらにより表面原子の配列状態， 電荷の分布, 吸着の强さ, 表面化合物の組成や量などを 知ることができる。

一方電気化学では，電極/電解質の接触界面を取り扱 らので，真空中で観測することを要求する上述の有力手 段住使用不可能である。また，かりに観測できたにして も溶媒分子の電極面における配向, 電解質の種類, 濃度 とか，電極電位の影響など複雑な要因を考慮しなくては ならない，電極を電解系外に取り出して．上記各種の観 測にかけることができるが，これでは，電解質と接して 電位がかかっている十マの状態をみたことにならず, “電 極界面”の消失した系しか観測できない．また従来イン ピーダンス法などを適用して水銀電極界面の吟味が詳し くなされてきたが，表面を理想的な状態で常に清浄に保 つことの困難な固体電極界面の研究に注電気化学手法だ けでは隔靴择庠の感があった。

そこで電極の動作しているままの状態に保ちつつ界面 の様子を直接的に観测する in situ 法が強く要求される わけであるが，光の反射を利用する方法はこの面から有 力な手段之考えられる.その原理は古典的な Maxwell の電磁方程式に基礎を膡いているが，えられる知見は分 子レベルに及び，吸着の観測にも威力を発揮する. 光を 用いる方法には，ほかに Photoemission 上か Photocurrent を利用寸る方法むあり，それぞれ有用ではある がまだ確立された手法には至っていないのでその記述は 行わない，本講では光の反射を利用する方法のあらまし を述べる(1).

\footnotetext{
* 東京芝浦電気 (株) 総合研究所（川㥓市区小向東芝町 1 ）
}

光のパスに着目して分類すると，

1) 内部反射法 (Internal reflection method)

2) 外部反射法 (External reflection method)

に分けられる，前者は図 1 (a)に示したように，透明

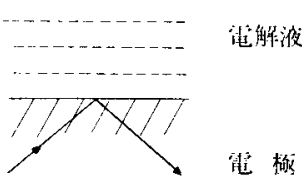

(a)

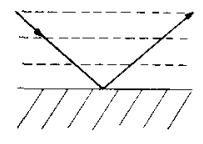

(b)
网 1 内部反射（a）と外部反射（b)

な電極体内部に導入した光を界面に全反射する上うな入 射角で導く方法で, 後者はこの逆任電解液側から電極面 に光をあてる (b) 方法である.内部反射法では光の電界 が電解液側にしみ出すことにより界面近傍の情報がえら れるという性質を利用している。両法とも，通常は電極 面を鏡面仕上げして乱反射がないような条件で測定する (鏡面反射, specular reflection).

一方測定法から考えると，1) 偏光解析法 (Ellipsometry，エリプソメトリー)．2）鏡面反射法 (Specular reflection method), 3) エレクトロレフレクタンス法(Electroreflectance method) などがある.上述の分類による 内部および外部反射法ともこれら三種の手法に適用可能 である・本講では, これら全体につき解説する。

\section{3 光 と 偏 光 $^{5}$}

光は電磁波の一種, 横波であり電気変位と磁気変位は 進行方向に垂直に振動している. 磁気変位のベクトル 法, 電気変位のベクトルと直交しているので, 透磁率が 波長などに無関倸に一定である場合は, 電気べクトルだ け考えればよい. 单色光の性質として, 振動数 (波長), 
振巾, 進行方向, 位相, 振動のむきなどがあるが, 振動 のむきと大きさ（電気ベクトル）と位相が偏光を記述す るのに重要な因子である.

光の進行方向に直交する一つの平面上で振動電場の強 さを観測したばあい，これが急速に不規則な変化をする が，時間をかけ平均值をとるとどの方向にも均等である とき,これを自然光という。一つの直線内だけで振動し ているとき直線偏光，ある特定の方向に偏りのあるとき 部分偏光とよぶ.通常の光は多少とも偏光になっている.

図 2 亿示すように電気ベクトルがダ円的に規則变化す るような光をダ円偏光と呼ぶ.ダ円の長軸と短軸が等し いときは円偏光という. 一般にダ円偏光は, 振巾と位相 の相異なる二つの直線偏光の合成である. 振巾相等しく 位相が $90^{\circ}$ 異なる二つの直線偏光を重礼ると円偏光とな る.

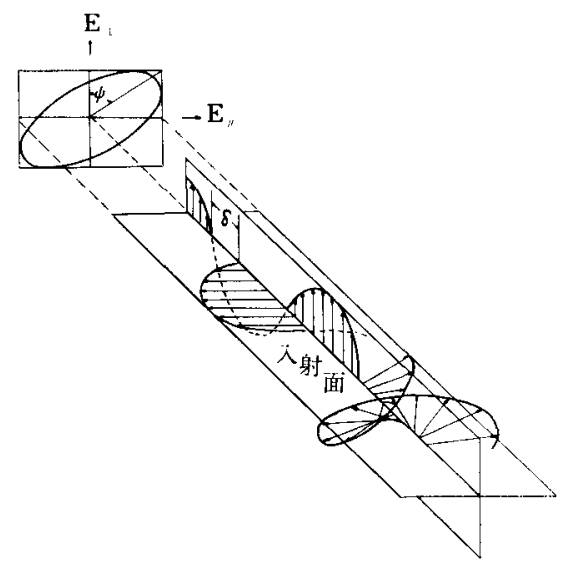

図 2 ダ円偏光を構成する二つの直線偏光と圭の振引 $E$ と位相差 $\delta$

図 2 から明らかなように, ダ円偏光は二つの直線偏光 飞分解できる.そして二つの直交する面XとYの上に投 㔀したとき (1) その面上での振巾 $E_{\mathrm{x}}{ }^{0} と E_{\mathrm{y}}{ }^{0}$ の比, (2)この二つの直線偏光の位相差 $\delta_{\mathbf{x}}{ }^{\mathrm{i}}-\delta_{\mathbf{y}}{ }^{\mathrm{i}}=\Delta^{\mathrm{i}}$ の二つが 反射に関する重要な因子である.

\section{4 光の伝播と媒体の物性 ${ }^{2), 5)}$}

光が媒体中を伝播するとき，媒体の誘電率 $\hat{\varepsilon} か ゙$ 光の性

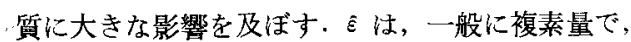

$$
\hat{\varepsilon}=-\varepsilon^{\prime}-i \varepsilon^{\prime \prime}(i=\sqrt{-1})
$$

で示される. そして実数部分 $\varepsilon^{\prime}$ は, 媒体の各構成分子 やその集団としての各種分極率の総和であり, 虚数部分 $\varepsilon^{\prime \prime}$ は, 各種導電率の総和である. 媒体の屈折率 $\hat{n}$ も複 素量で,

$$
\hat{n}=n-i k
$$

で与えられる.ここに屈折率 $n$ 抢よび消衰保数 $k$ は

$$
\varepsilon^{\prime}=n^{2}-k^{2}, \quad \varepsilon^{\prime \prime}=2 n k
$$

の関係にある.媒体が光を吸収する性質があるとき $k \doteq 0$ であり，いわゆる吸光係数 $\alpha$ ととは（4）で結ばれる. $\alpha=2 \pi k / \lambda$

\section{ここにネは光の波長.}

$\varepsilon^{\prime \prime}$ やが0でないとき光は進行に伴い媒体にその工 ホルギーを吸収され振仍減衰してゆくが は減衰がない， $E_{\mathrm{y}}{ }^{\circ} や ， \delta_{\mathrm{x}}, \delta_{\mathrm{y}}$ は変化しないが， $\hat{\varepsilon}$ の異なる媒体中入入 ると，そのさいこれらの量が変化する，その変化した是 を測定すると，媒体の物性 $气$ を知ることができる。

\section{5 光 の 反 射 $^{2,5)}$}

光が，相異な石光学的性質をむった二つの媒体の接す る平面で反射寸るとき(図 3 ), 入射光 ( $i$ と添字) と反射 光 $(r$ と添字) の性質を比較することにより界面の性質

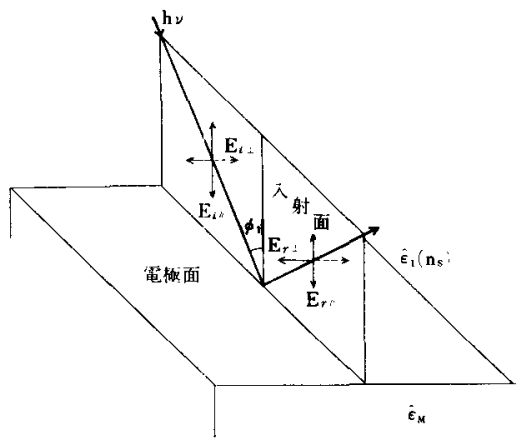

図 3 光の反射と $E$ の強さの变化

を知ることができる，反射のさいつぎの変化がある、(1) $\boldsymbol{E}_{\mathbf{i}}$ と $\boldsymbol{E}_{\mathrm{r}}$ とが異なる, 入射面(図 3 参照, 界面に垂值) に平行な $\boldsymbol{E}$ の成分を $E_{/}\left(E_{\mathrm{p}}\right)$, またこれさ垂直な成分 を $E_{\perp}\left(E_{\mathrm{s}}\right)$ とすると一般に

$$
E_{\mathrm{i} / /}>E_{\mathrm{r} / /}, \quad E_{\mathrm{i} \perp}<E_{\mathrm{r} \perp}
$$

寸なわち反射光は, 入射面に垂直な成分が強い上うに偏

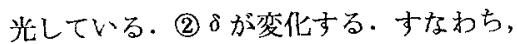

$$
\delta_{1,}{ }^{\mathrm{i}}-\delta_{\perp}{ }^{\mathrm{i}}=\Delta^{\mathrm{i}}, \quad \delta_{\prime \prime}{ }^{\mathrm{r}}-\delta_{\perp}{ }^{\mathrm{r}}=\Delta^{\mathrm{r}}
$$

としたとき，

$$
\Delta^{\mathrm{r}}-\Delta^{\mathrm{i}}=\Delta \neq 0
$$

である・

\section{1 鏡面反射の基本式}

図 3 に拉りる上の相が光学的に粗, 下の相が密である とき, 粗の相から密の相に向い光が入射寸るばあいを考 える. 入射光の强さを $I_{0}$, 反射光のそ机を $I$ とすると, 度射率 $R_{0}$ は，

$$
R_{0}=I / I_{0}=\frac{1}{2}\left(K_{1,0}+R_{\ell, 0}\right)
$$


ここに $R_{\perp, 0}, R_{1,0}$ は, それぞれ入射面に垂直および並 行な直線偏光の反射率で次式により与えられる.

$$
R_{\perp, 0}=\hat{r}_{\perp_{12}} \cdot \hat{r}_{\perp_{12}} *, R_{1 /, 0}=\hat{r}_{1 / 12} \cdot \hat{r}_{1 / 12} * \text { (9) }
$$

$\hat{r}^{*}$ は反射係数 $\hat{r}$ の複素共役で, $\dot{r}$ は

$$
\xi_{1}=\hat{n}_{1} \cos \phi_{1}, \quad \xi_{2}=\hat{n}_{2} \cos \phi_{2}
$$

在用いて (11) と（12）で与えられる。

$$
\hat{r}_{\perp_{12}}=\frac{\xi_{1}-\xi_{2}}{\xi_{1}+\xi_{2}} \quad(11), \quad \hat{r}_{1 / 12}=\begin{aligned}
& \hat{\varepsilon}_{1} \xi_{1}-\hat{\varepsilon}_{1} \xi_{2} \\
& \hat{\varepsilon}_{2} \xi_{1}+\hat{\varepsilon}_{2} \xi_{2}
\end{aligned}
$$

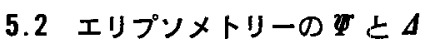

$\hat{r}_{12}$ はつぎの形でる示すことができる.

$$
\begin{aligned}
& \hat{r}_{\perp_{12}}=\frac{E_{\perp_{2}}}{E_{\perp_{1}}}=\frac{\left|E_{\perp_{2}}\right|}{\left|E_{\perp_{1}}\right|} \cdot e^{i\left(\delta \perp_{2}-\delta \perp_{1}\right)} \\
& \hat{r}_{/ / 12}=\frac{E_{/ / 2}}{E_{/ / 2}}=\frac{\left|E_{/ / 2}\right|}{\left|E_{/ / 2}\right|} \cdot e^{i\left(\delta_{/ / 2}-\delta_{/ / 2}\right)}
\end{aligned}
$$

ここに $|E|$ は $E$ の絶対值, 上記二つの $r$ の比 $\rho$ 注,

$$
\begin{aligned}
& \rho_{12}=\frac{\hat{r}_{/ 11^{2}}}{\hat{r}_{\perp_{12}}}=\frac{\left|E_{/ / 2}\right|}{\left|E_{/ / 1}\right|} / \frac{\left|E_{\perp_{2}}\right|}{\left|E_{\perp_{1}}\right|} \cdot e^{i\left[\left(\delta_{/ / 2}-\hat{\delta}_{/ / 1}\right)-\left(\delta \perp_{2}-\delta \perp_{1}\right)\right]} \\
& =\tan \psi_{0} \cdot e^{i \Delta_{0}}
\end{aligned}
$$

$こ こ に \tan \psi r_{0}=\frac{\left|E_{/ / 2}\right|}{\left|E_{h_{1}}\right|} / \frac{\left|E_{L_{2}}\right|}{\left|E_{L_{1}}\right|}, \Delta_{0}=\left[\left(\delta_{/ / 2}-\delta_{/ / 1}\right)-\left(\delta_{\perp_{2}}\right.\right.$ $\left.\left.-\delta_{\perp 1}\right)\right]$

寸なわち $\psi_{0}$ 注振巾の比の入射光と反射光に関する割合 老示し， $\Delta_{0}$ は反射のさいの位相の変化老示寸.

\section{6 電極面に薄膜層が存在するとき23,5}

通常電極界面には, 㹡散層, ヘルムホルッ層, 特異吸着 層, 酸化層, 空間電荷層などオングストローム単位の厚 さの層が 2 種以上共存積層している。これらの層の バルクの相 (たとえば電解液)のミとは異なるため，こ の相の存在に基づく変化量が期待される.

いま図 4 に示すように光学的性質や厚さの異なる $l-1$

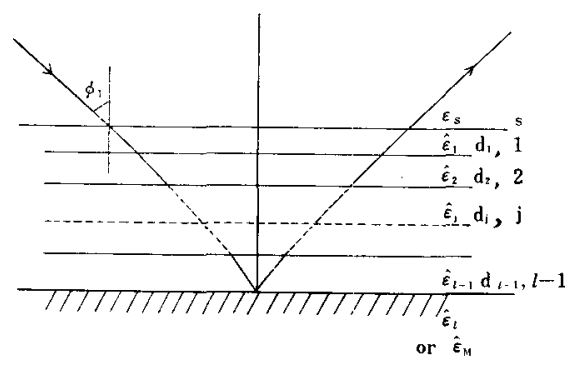

図 4 多層に打的射

個の薄層が基体上に積層しているとき $j$ 番目の層の厚さ を $d_{\mathrm{j}}$ とすると, これらによる反射率の変化量は,

$$
\begin{aligned}
& \left(\frac{\Delta R}{R_{0}}\right)_{\perp \mathbf{t}}=\left(\frac{R-R_{0}}{R_{0}}\right)_{\perp}=\sum_{\mathrm{j}=1}^{1-1}\left(\frac{\Delta R}{R_{0}}\right)_{\perp, \mathrm{j}} \\
& \left(\frac{\Delta R}{R_{0}}\right)_{/ /, \mathrm{t}}=\left(\frac{R-R_{0}}{R_{0}}\right)_{\|}=\sum_{\mathrm{j}=1}^{1-1}\left(\frac{\Delta R}{R_{0}}\right)_{/, \mathrm{j}}
\end{aligned}
$$

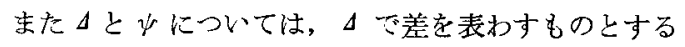
と

$$
\begin{aligned}
& \Delta \Delta_{\mathrm{t}}=\Delta_{\mathrm{film}}-\Delta_{0}=\sum_{\mathrm{j}=1}^{1-1} \Delta_{\mathrm{j}} \\
& \Delta \psi_{\mathrm{t}}=\psi_{\mathrm{film}}-\psi_{0}=\sum_{\mathrm{j}=1}^{1-1} \psi_{\mathrm{j}}
\end{aligned}
$$

内部反射法に扔いては, 膜の存在に基ら゙く吸光度の変 化を $\Delta A$ とすると，

$$
\begin{aligned}
& -\Delta A_{\perp}=\frac{1}{\ln 10}\left(\frac{\Delta R}{R_{0}}\right)_{\perp,} \\
& -\Delta A_{/ /}=\frac{1}{\ln 10}\left(\frac{\Delta R}{R_{0}}\right)_{/ /}
\end{aligned}
$$

これらの式加わかるよらに，いくつかの層が共存し ている場合でも反射率やエリプソメトリ一量の変化は, 各層に基づく変化量の単純な和で与えられ, 各層の寄与 を個々独立に吟味することができる。

それでは一つの薄層に由来寸る変化量はどのような物 理量で表わされるがを述心゙よう.基本式は，すでに今世 紀初頭 Drude によって導かれた・薄層が十分薄いとき は，非常に簡単化される。すなわち $j$ 層については，

$$
\begin{aligned}
& \left(\frac{\Delta R}{R_{0}}\right)_{\perp, \mathbf{j}}=\frac{8 \pi n_{\mathrm{s}} d_{\mathbf{j}} \cos \phi_{1}}{\lambda} \operatorname{Im}\left(\frac{\hat{\varepsilon}_{\mathbf{j}}-\hat{\varepsilon}_{\mathbf{M}}}{n_{\mathbf{s}}{ }^{2}-\hat{\varepsilon}_{\mathbf{M}}}\right) \\
& \left(\frac{\Delta R}{R_{0}}\right)_{1 /, \mathrm{j}}=\frac{8 \pi n_{\mathrm{s}} d_{\mathrm{j}} \cos \phi_{1}}{\lambda} \\
& \operatorname{Im}\left\{\left(\frac{\hat{\varepsilon}_{\mathbf{j}}-\hat{\varepsilon}_{\mathbf{M}}}{n_{\mathbf{s}}{ }^{2}-\hat{\varepsilon}_{\mathbf{M}}}\right)\left[\frac{1-\left(n_{\mathbf{s}}{ }^{2} / \hat{\varepsilon}_{\mathbf{j}} \hat{\varepsilon}_{\mathbf{M}}\right)\left(\bar{\varepsilon}_{\mathbf{j}}+\hat{\varepsilon}_{\mathbf{M}}\right) \sin ^{2} \phi_{1}}{1-\left(1 / \hat{\varepsilon}_{\mathbf{j}}\right)\left(n_{\mathbf{s}}{ }^{2}+\tilde{\varepsilon}_{\mathbf{M}}\right) \sin ^{2} \phi_{1}}\right]\right\}
\end{aligned}
$$

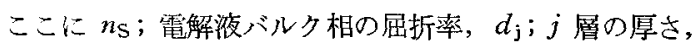
$\lambda$; 真空中での入射光の波長， $\phi_{1}$; 入射角， $\bar{\varepsilon}_{\mathbf{j}} ; j$ 層の $\bar{\varepsilon}$, $\tilde{\varepsilon}_{M}$; 電極バルク相の $\bar{\varepsilon}, \operatorname{Im}$; 複素量の虚数部分.

この式はきわめて有用である、すなわち反射率の変化 は膜厚に比例し，着目層とバルク相の誘電率だけが変化 に寄与する物理量であることを示している。

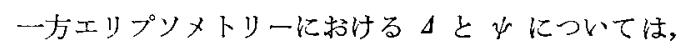

$$
\begin{aligned}
& \Delta_{\mathrm{j}}-\Delta_{0}=\Delta \Delta_{1}=\mathrm{a} d_{\mathbf{j}} \\
& \psi_{\mathrm{i}}-\psi_{0}=\Delta \psi_{\mathrm{j}}=\mathrm{b} d_{\mathrm{j}}
\end{aligned}
$$

の関倸があり， $R$ と同様に $d_{\mathrm{j}}$ に比例した変化がある. ここに a, b はそ机ぞれ $\varepsilon_{\mathrm{j}}, n_{\mathrm{S}}, \hat{\varepsilon}_{\mathrm{M}}, \lambda, \phi_{1}$ の関数であ るが、これらが一定の条件下では定数となる。

\section{7 吸着量と $R, \phi, \Delta$ との関係 ${ }^{2}$}

前節では薄層が電極全面をおおっているときを考えた が部分的被覆すなわち単分子層以下の被覆のばあいにも 同様の比例関係が成立する. 途中の演算は省略して結果 だけ述バると，

$$
\left(\frac{\Delta R}{R_{0}}\right)_{\theta}=\left(\frac{\Delta R}{R_{0}}\right)_{\mathrm{ad}} \cdot \theta
$$

ここに左辺は被覆率 $\theta$ のときの吸着層に基づく反射率变 化（） $\mathrm{ad}$ は $d_{\mathrm{j}}$ =吸着層の厚さとしたときの $\theta=1$ にお

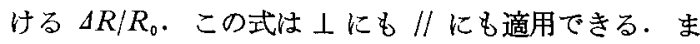
た $\alpha$ おび $\beta$ を定数とすると，下式が成立する. 


$$
\Delta \Delta_{\theta}=\Delta_{\mathrm{ad}}-\Delta_{\mathrm{a}}=\alpha \cdot \theta, \quad \Delta \psi_{\theta}=\psi_{\mathrm{ad}}-\psi_{0}=\beta \cdot \theta
$$

\section{8 測 定 法 ${ }^{2)}$ (4),7}

\section{1 鏡面反射法(4),7)}

図 5 亿示した円筒型セル(石英製がよい)の中心部板 状の電極(よく摩いた板でもよく,ガラス板上への蒸着 膜でもよい）を配置し，単色光を一定入射角で電極上に 入射しつつ, 電解を行わせる. 反射光を光電子撂倍管で
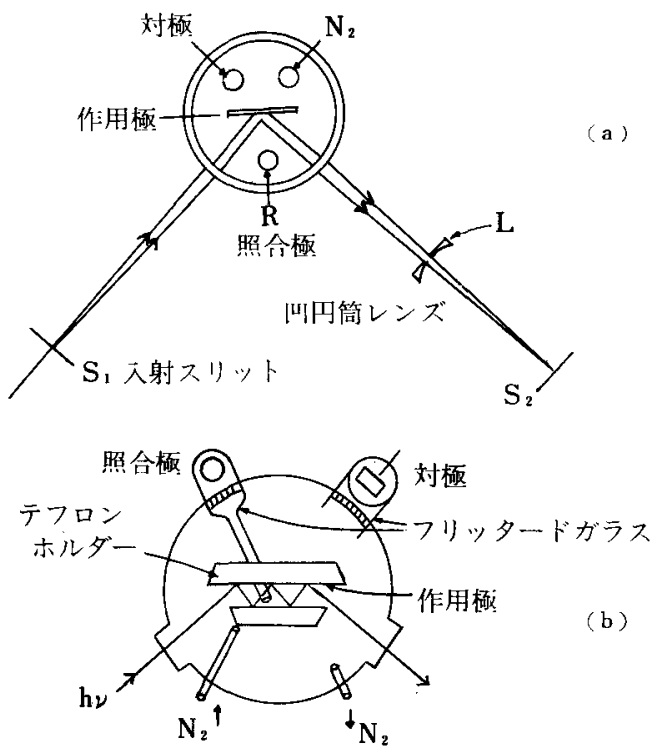

図 5 多重反射用セル (a) J. Horkans, in ref. 1, (b) 高村 5 , ref. 10

検知し, 出力を増幅し $\mathrm{X}-\mathrm{Y}$ 記録計 $\mathrm{Y}$ 軸に入れる。電 解は，三電極法で行い，電位走查法のばあい，電位を $\mathrm{X}$ 軸に入れ， $R / R_{0}-E$ 曲線を描かせる. 同時に $i-E$ (電流一

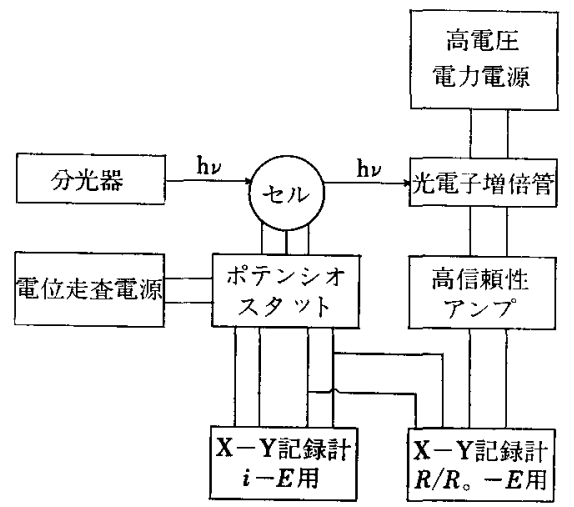

図 $6 R / R_{\mathrm{a}}$ 測定のブロックダイヤグラム
電圧）曲線安記録する．光学および回路系模式図を図 6 に示す. 電極の大きさは，電極面上に集光する光源像の 大きさより大きくする $(10 \times 15 \mathrm{~mm}$ 程度).

\section{2 エリプソメトリーー2),6)}

市販エリプソメータを使用した方が簡便である。その 光学系模式図を図 7 亿示す. 光源加らの強い単色光はポ ラライザ $P$ により直線偏光になり，ついで入射面に対 し 45に方位角をセットした $1 / 4$ 波長板 $Q$ によりダ円 偏光にされる。これが試料面に一定の入射角で入射す る. 反射光が直線偏光となるよう $P$ 䘮回転調節する。

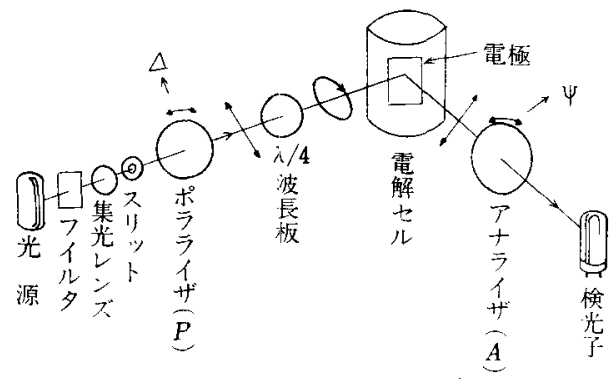

図 7 エリプソメータの配置搆成

直線偏光の傾きは $A$ を回転して探す. $A$ を通過した光 を光検出器でうけ，その出力がゼロになる（消光点）よ うに $P$ と $A$ の回転角を調節するのである.そのとき の $P$ と $A$ の方位角の読文から

\section{3 内部反射法 ${ }^{2,8}$ )}

ガラス板に酸化スズを薄くコートした膜は光透過性よ

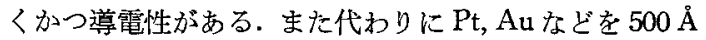
程度の膜厚に蒸着してもよい，この光透明電極 (Optical Transparent Electrode，OTE) を用い，図8のような

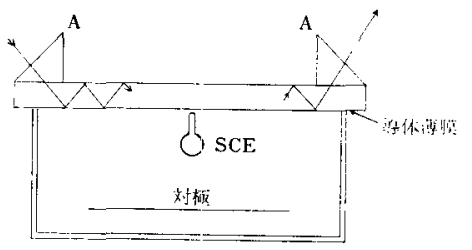

図 8 内部反射電解セルの一例

構成で多重反射による測定を行うことができる. 光導入 (出)用プリズム A は OTE 基板と同種のものがよく, 接触面を光学平面仕上げすれば，圧着だけで密着でき る.

\subsection{Electromodulation 法 $^{9)}$}

原理を図 9 に示す. 電位走查法で電解しているとき, $\pm A E$ の振巾をもった交流を分極電压に重畳すると，こ れに応じて反射率には土 $A R$ の振巾をもった交流が重鳁 する.この交流部分だけをロックインアンプにより増幅 し， $E$ に対する $R$ の微行曲線をらる方法であり，反射 
率として $10^{-4} \sim 10^{-6}$ 程度の変化の微小検知が可能であ る.

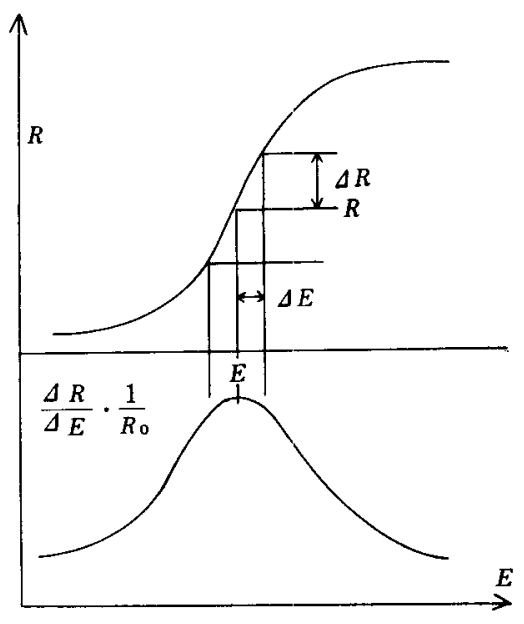

図 9 Electromodulation

\section{9 実例 $\sigma$ 紹 介}

\section{1 基礎液中における固体 (極 $^{1,3), 10>}$}

たとえば $1 \mathrm{M} \mathrm{HClO}$ ，基礎液とし，この中で $\mathrm{Au}$ 極 を用いて三角波ボルタンメトリーを行うと, 図 10 破線 に示す $i-E$ 曲線がえられる. 非常に幅広い二重層領域 と, 明りょうな酸化層形成領域がみられる. 同時に測定 した反射率一電位 $\left(R / R_{0}-E\right)$ 曲線は実線のようであり，

二重層領域では正電位側にゆくにつれ $R / R_{0}$ が直線的に 減少している.しかし酸化層形成の電流が流れると同時

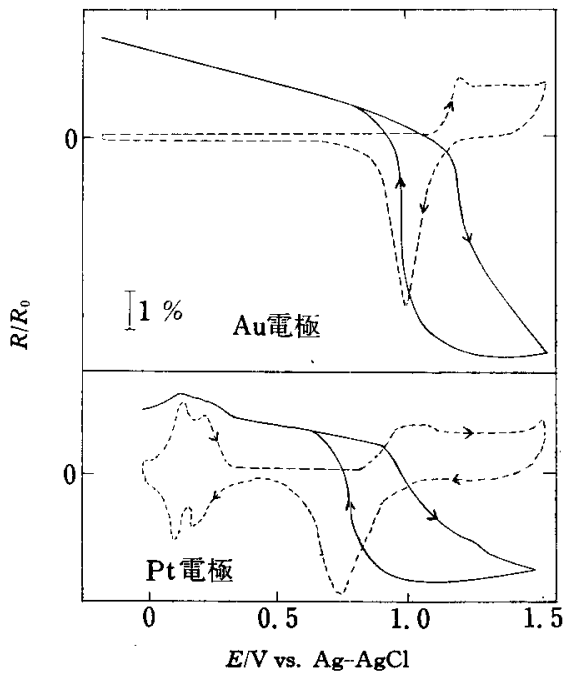

図10 $1 M \mathrm{HClO}_{1}$ に批引 $\mathrm{Au}$ 極 (上) と $\mathrm{Pt}$ 極 (下) の $i-E$ (破線)， $R / R_{0}-E$ (実線) 曲線
に $R / R_{0}$ 注著しい減少を開始，酸化層がふえつつけて いる間中減少している. 電位走查を折り返すと $R / R_{0}$ は， $i-E$ 曲線に還元電流があらわれるまでほぼ一定であ るが酸化層の還元開始とともに増加を始め, 還元ピーク が消失した電位では，もとの值に復帰する．この酸化層 の形成による $R / R_{0}$ の減少は (22) の $\bar{\varepsilon}$ を(1) 式に よって書きかえた（28）式により表わされ, 酸化層の厚 さ $d_{\mathrm{ox}}$ と $\Delta R / R_{0}$ とが比例することを示す.

$$
\begin{aligned}
& \left(\frac{\Delta R}{R_{0}}\right)_{-, \mathrm{ox}}=-8 \pi d_{\mathrm{ox}} n_{\mathrm{S}} \cos \phi_{\mathrm{L}} \\
& \text { - } \frac{\varepsilon^{\prime \prime} \circ\left(n_{S^{2}}-\varepsilon_{M^{\prime}}\right)+\varepsilon^{\prime \prime} \mathbf{M}\left(\varepsilon_{o x}^{\prime}-n_{S^{2}}\right)}{\left(n_{\mathrm{S}}{ }^{2}-\varepsilon^{\prime} \mathbf{M}\right)^{2}+\varepsilon^{\prime \prime} M^{2}}
\end{aligned}
$$

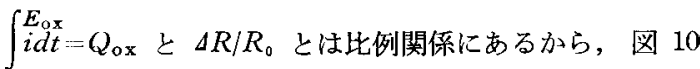
の $i-E$ 曲線を積分して求めた $Q-E$ 曲線は $\Delta R / R_{0}-E$ 曲 線と同じ形を与えるべきである・実測は，图 11 に示す ように同じ形を与える.同様な形は $\psi-E$ および $\Delta-E$ 曲線にもみられる(伩 11).

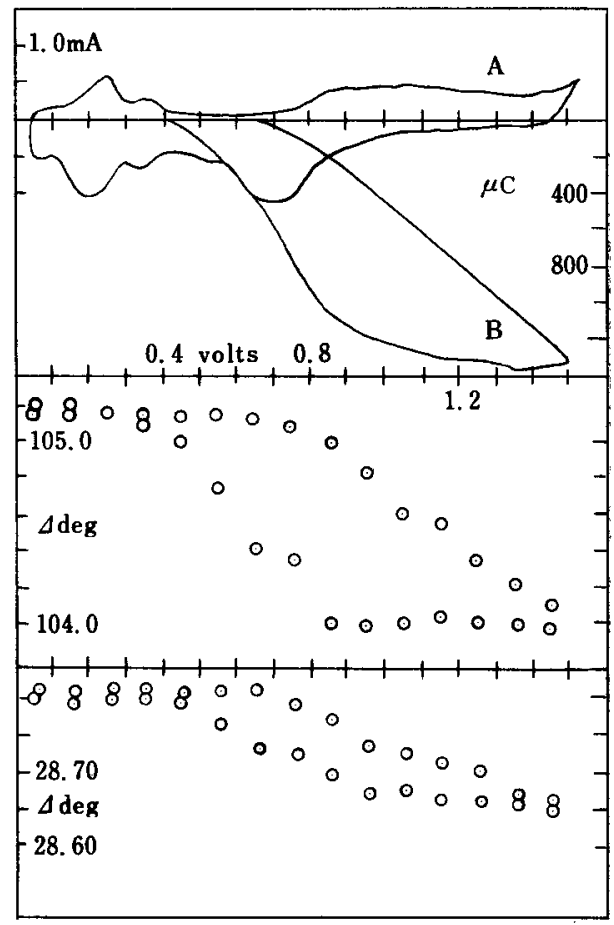

因 $111 M \mathrm{HClO}_{4}$ に打汀 $\mathrm{Pt}$ 極の $i-E$ 曲線(A), $Q-E$ 曲線 (B) 和よび $\Delta-E, \psi-E$ 曲線 (下の 2 図)

つぎに， $\hat{\varepsilon}_{\mathrm{M}}$ と $n_{\mathrm{S}}$ は既知であり $d_{\mathrm{ox}}$ が適当な方法で

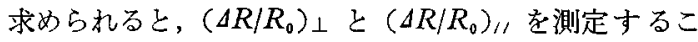
とにより (22) と（23）加ら $\varepsilon^{\prime}$ ox と $\varepsilon^{\prime \prime}$ ox が求まる. これを種々の入で測定し酸化層のスペクトルをらること ができる.これらの量から，酸化層の半導体性，バンド キャップ，金属原子の䏇移に関する責重な情報がえられ 


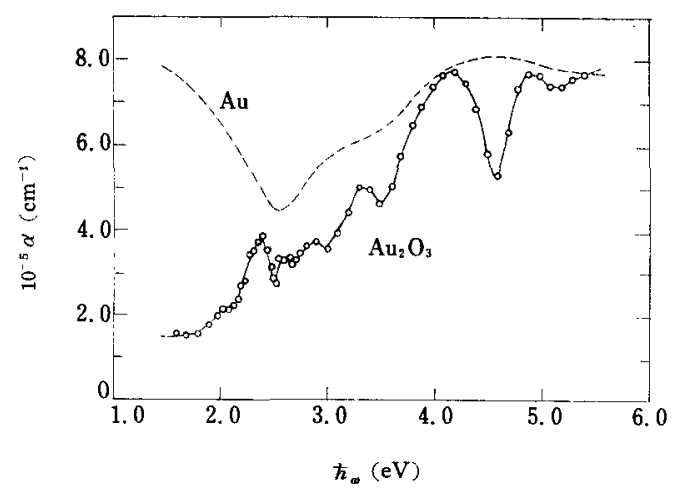

图 $12 \mathrm{Au}$ 金属と，この上にアノード分極で生成させ た酸化膜との吸収スペクトル(酸化膜の組成は $\mathrm{Au}_{2} \mathrm{O}_{3}$ と仮定した）

D.M. Kolb and J.D.E. McIntyre, Surf. Sci., 28, 321 (1971)

る.スペクトルの一例を図 12 に示す ${ }^{2)}$.

Pt では, 祘知の通り $0 \sim 300 \mathrm{mV}$ の間に吸着水素 $\left(\mathrm{H}_{\mathrm{ad}}\right)$ の生成にもとづく二つの電流ピークがえられる.

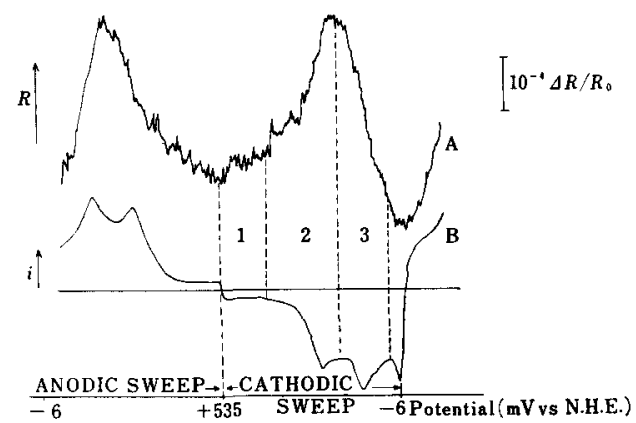

図 $13 \quad 1.0 M \mathrm{H}_{2} \mathrm{SO}$ 、に抢ける $\mathrm{Pt}$ 電極の $\Delta R / R_{0}-E(\mathrm{~A})$ および $i-E(\mathrm{~B})$ 曲線

1: 二重層頒城，2：强い吸着力の $\mathrm{Had}$

3: 弱々吸着力の $\mathrm{Had}, 440 \mathrm{~nm}, \phi_{1}=70^{\circ}, \mathrm{s}$ 偏光:

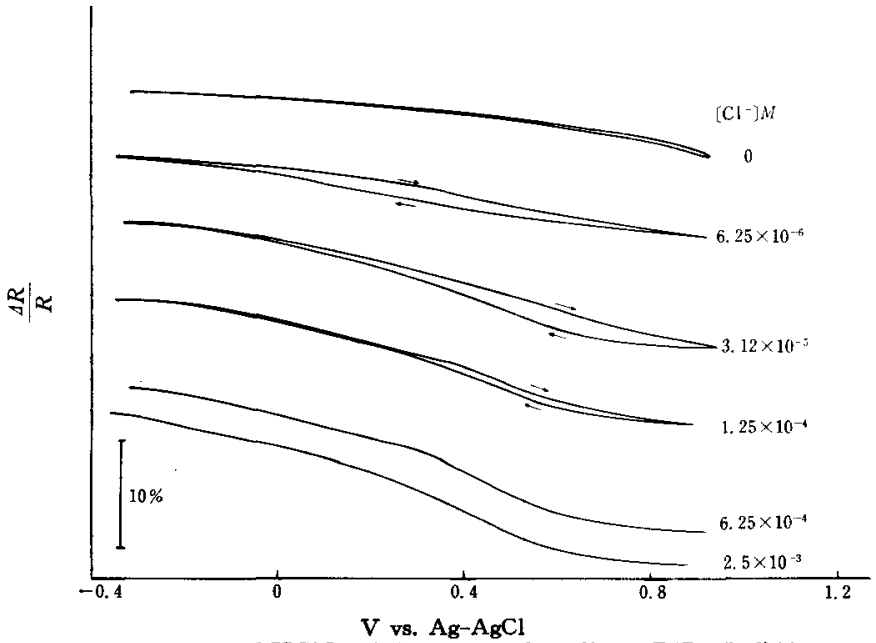

図 $150.2 M \mathrm{HClO}_{4}$ 溶液沛打る $\mathrm{Au}$ 電極の $R / R_{0}-E$ 曲線 $\mathrm{Cl}^{-}$の量の増加によって $R / R_{0} か ゙ 0.4 \mathrm{~V}$ ちかくて念に減少す。
同時に $\Delta R / R_{0}$ （あるい活 $\psi ， \Delta$ ) vs. $E$ 曲線をとると， このピークに対応してわづかではあるが増加と減少とが みられる（図 13）。データを解折して $\mathrm{H}_{\mathrm{ad}}$ の $\hat{\varepsilon}$ を求め てみると，正電位側の $\mathrm{H}_{\mathrm{ad}}$ は金属イオンに近い形で吸 着しており，負電位側の $\mathrm{H}_{\mathrm{ad}}$ 注中性原子に近い状態で あることを示す。

\section{2 アニオンの吸尊 ${ }^{2) \sim 4}$}

アニオン吸着は, $R / R_{0}$ の減少をむたらし, その変化は (26) で示すように $\theta$ に比例する. $\Delta$ 中 の変化も $\theta$ に比例寸る (27 式).この比例性を利用し光学測定によ り $\theta$ を求め, これにより吸着機構を解折することができ る. Genshaw らはエリプソメトリーによりアニオンの 電気化学吸着量 一電位の関係を求めた。一例を図 14 に 示寸 ${ }^{11}$.

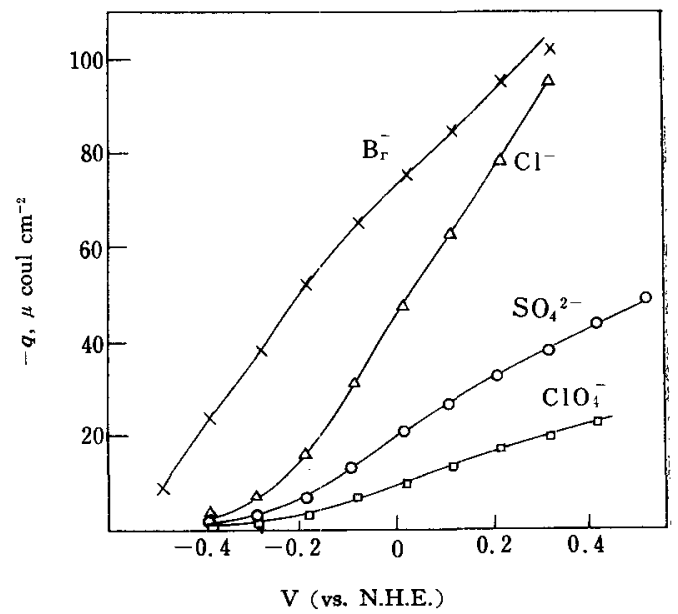

図 $14 \quad 10^{-2} M$ の溶液から吸着させたばあいの $\mathrm{Ag}$ 電極へ の各種アニオン吸着の電位依存性

W. Paik et al., J. Phys. Chem. 74, 4266 (1970)

$R / R_{0}$ が吸着によって変化する様子 を $E$ の関数として調べるに注電位走 查法が簡便である・Au の二重層領域 内で $R / R_{0}-E$ 曲線を $\mathrm{Cl}-$ の存在の下 で調ぶると図 15 のような曲線がえら れる. 負電位側では $\mathrm{Cl}^{-}$の吸着量は 少いが，ある電位に達すると吸着が顕 著になりここで $R / R_{0}$ の減少が著し い.この変化の激しい電位はアニオン の種類すなわち吸着力の大小により異 なる・よって $\Delta R / R$ が著しくなる電位 に着目し各アニオンの吸着力の差を容 易に知ることができるＡu につき調 べたところ $1 \mathrm{MHClO}_{4}$ 中では, I-> $\mathrm{B}_{\mathrm{r}}{ }^{-}>\mathrm{PO}_{4}{ }^{3-} \sim \mathrm{Cl}^{-}>\mathrm{SO}_{4}{ }^{2-}>\mathrm{NO}_{3}{ }^{-}>$ $\mathrm{ClO}_{4}$-の順で吸着力が小さくなってい 
ることが分った。

最初電位を十分負の一定値に保ち分極したのち，吸着 か゚盛になる電位にステップし $R / R_{0}$ と時間 $(t)$ との関 係を記録し吸着の動的過程を知ることもできる．R/R- $t$ 曲線を $\sqrt{t}$ に対しプロットし直すと原点を通る直線にな り [Cl-] の小さいとき吸着過程は昖散律速であること がわかった。

\section{3 アノート酸化層 $\left.\left.{ }^{1,2}, 2,4\right), 62,12\right)$}

$\mathrm{Ni}, \mathrm{Fe}, \mathrm{Cr}$ などは中性〜弱アルカリ性溶液中で酸化 すると，ある電位領域で，不働態膜が表面に形成され る.この膜厚は,たかだか数十オングストロームで,その 組成怯電位により異なる。これらの事実は, 電解液中で アノード分極しつつエリプソメトリーの測定を行った結 果から判明した．Ni ヒついての例を図 16 に示す. Ni

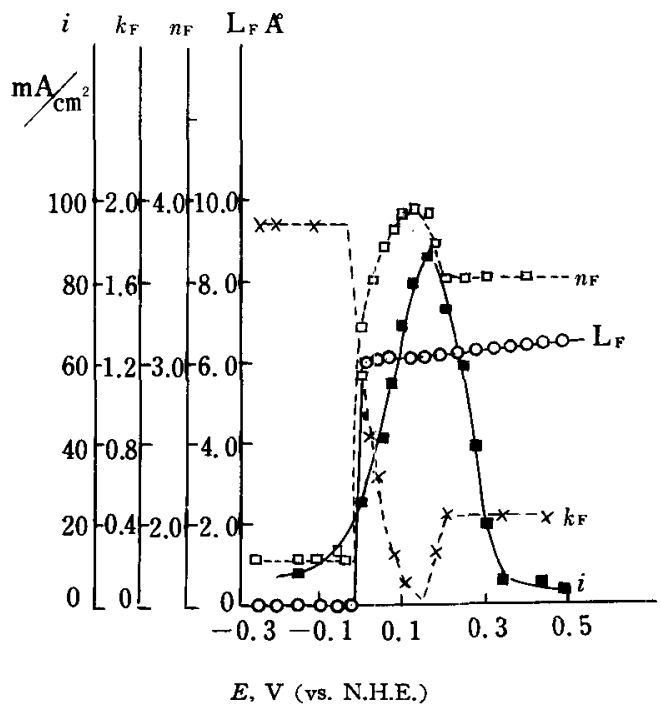

図 $16 \mathrm{H}_{2} \mathrm{SO}_{4}+\mathrm{Na}_{2} \mathrm{SO}_{4}(\mathrm{pH} 3)$ に和证吉 $\mathrm{Ni}$ 分極時 の $n_{F}, k_{F}$ の変化

は弱酸性から不働態膜を形成するが，0Vよりも負では 金属状態で， $0 \mathrm{~V}$ 付近加ら溶解が始をるが，すぐに $60 \AA$ ぐらいの水酸化物の膜が形成する.これは $k=0$ の絶緣 体としての性質を示寸方， $0.2 \mathrm{~V}$ では $k=0.4$ の半導体 的性質をもった不働態となることが明らかになっだ

\section{4 電気二重層 ${ }^{1>4}$}

ゼロ電荷電位 $(\mathrm{pzc})$ 以外の電位では, 二重層中のイオン 濃度は正負いづれかのイオンが多くなっている.一般に イオンの分子屈折は水の分子屈折より大きいため, pzc 以外の電位領域での二重層の屈折率注バルク溶液のそれ より大きい，pzc からのへだたりが大きい核ど差は著し くなる.このため (22) や（26）式からもわかると㧍り $\Delta R / R_{0} や \Delta \Delta, \Delta \psi$ が観測され，その絶対值の大きさは pzc を中心として大きくなる，このように電解液側の二
重層の存在によっても光の反射に影響があらわれる。 イオンの分子屈折上二重層の厚さが既知であれば， $\Delta R / R_{0}$ や $\Delta, \psi$ t測定することにより二重層中のイオン 濃度を知ることができる。これにより pzc を推定するこ とも可能である.

\section{5 有機化合物の吸着}

有機化合物の $n$ も一般にバルク溶液の $n_{\mathrm{S}}$ とは異な るので, 9.2 や 9.4 で述べたと同じ理由により, $\Delta R / R_{0}$, $\Delta \Delta$ などが，吸着により観察される. (26) を利用して $\theta$ を求めることもでき, これにより吸着等温線を求め, 吸 着機構を解析することができる.

非水溶媒中での観測も可能である. $0.25 \mathrm{M} \mathrm{NaClO}$ 、 を含む 2 メキシエタノールに芳香多環化合物を溶加 し, これらを $\mathrm{Au}$ 電極に吸着させたときの例を図 17 に 示す. 吸着により $R / R_{0}$ は隇少するので, その変化が

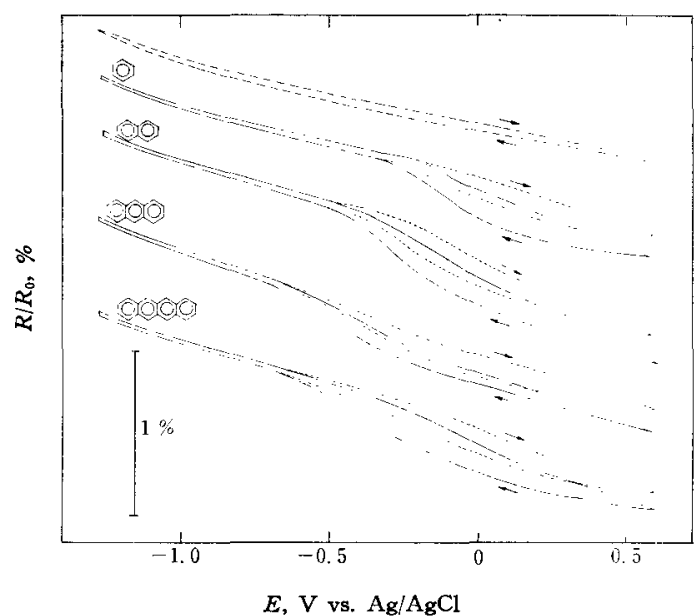

図 $170.25 \mathrm{M} \mathrm{NaClO}$ 4を含む 2 メトキシエタノール 中で測定した $\mathrm{Au}$ 電極の $R / R_{0}-E$ 曲線. 溶液

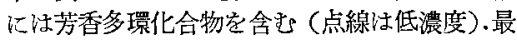
上注基濋液の夕。

最も著しい電位を各化合物 (ベンゼン,ナフタレン, ア ントラセン等）につき比較すると，芳香環の多い化合物 ほどより頁の電位から吸着することがわかる，上汇述べ た手法により日を求め, 解析した結果, 吸着力は環数の 多いほど大きく，また吸着のさい電極面で置換する溶媒 分子の数も，環数の多い化合物ほど多いことがわかっ た.

$\mathrm{Au}$ 電極に $1 \mathrm{M} \mathrm{HClO}_{4}$ 溶液加ら吸着したチ才尿素の 挙動を電位走查法で調ぶた例を図 18 に示す, 吸着によ り反射率の大きな減少がみられる。しかし非常に正の電 位側では, チ才尿素がアノード酸化されるため, 反射率 の回復が幾分ではあるがみられる・非常に負の電位でも 脱着することがわかる. 


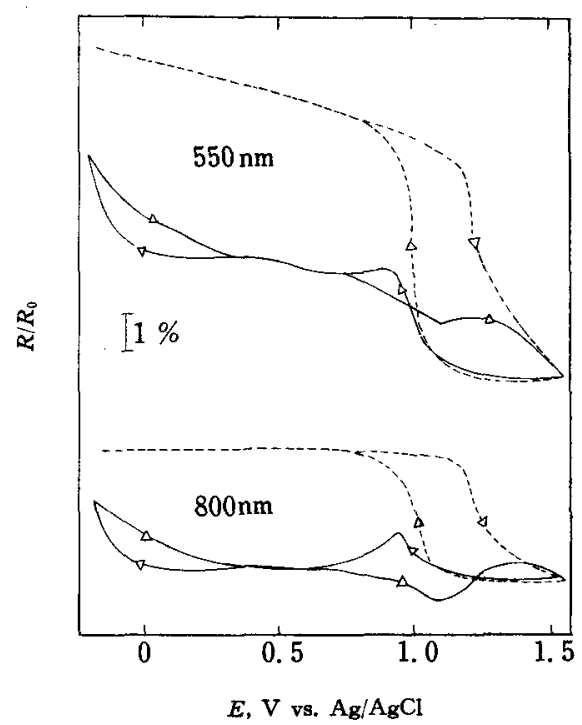

図 $181 \times 10^{-8} M$ 千才尿素を含さ $1 M \mathrm{MClO}$ ，中での $\mathrm{Au}$ 極に打ける $R / R_{0}-E$ 曲線

点綄：基碳液中の曲線（反射率は 5 回反射の值）

\section{6 金属原子層の形成 ${ }^{(2) 43,10), 15) ~}$}

固体金属電極の表面に異種金属層を形成させることは メッキそのものであるがメッキ相の光学定数が下地と異 なるため, 光学的変化として観測される。

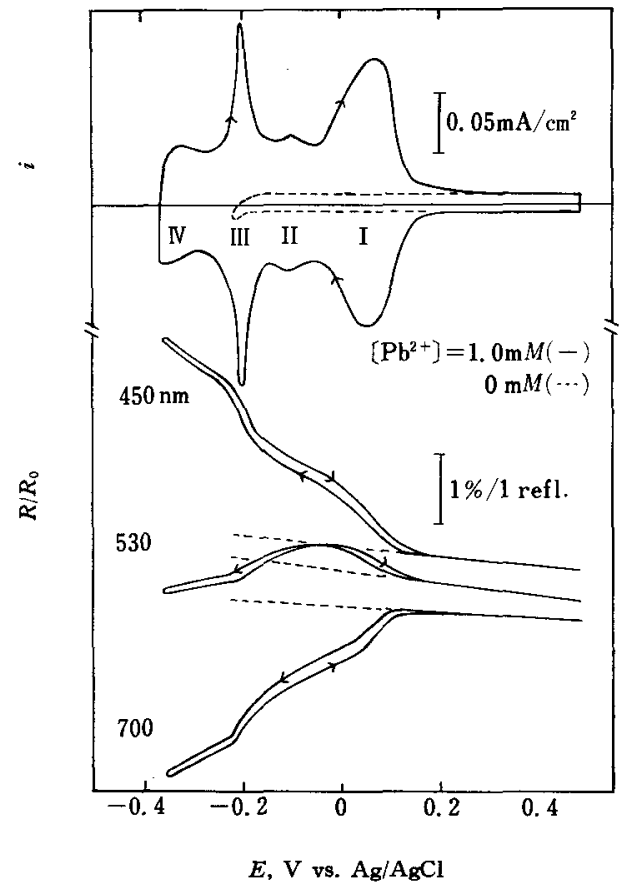

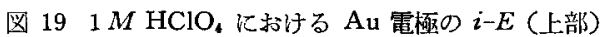
曲線と種々の波長に私ける $R / R_{0}-E$ (下部) 曲 線. $\mathrm{Pb}_{\mathrm{ad}}$ の生成による変化. 破線は $\mathrm{Pb}^{2+}$ 专 含ま基礎液における曲線
ことに最近アンダーポテンシャル領城で（29）により

$$
\mathrm{M}^{\mathrm{n}+}+n e \rightleftarrows \mathrm{M}_{\mathrm{ad}}
$$

異種金属吸着原子層 $\left(M_{\mathrm{ad}}\right)$ の形成に関する研究が注目

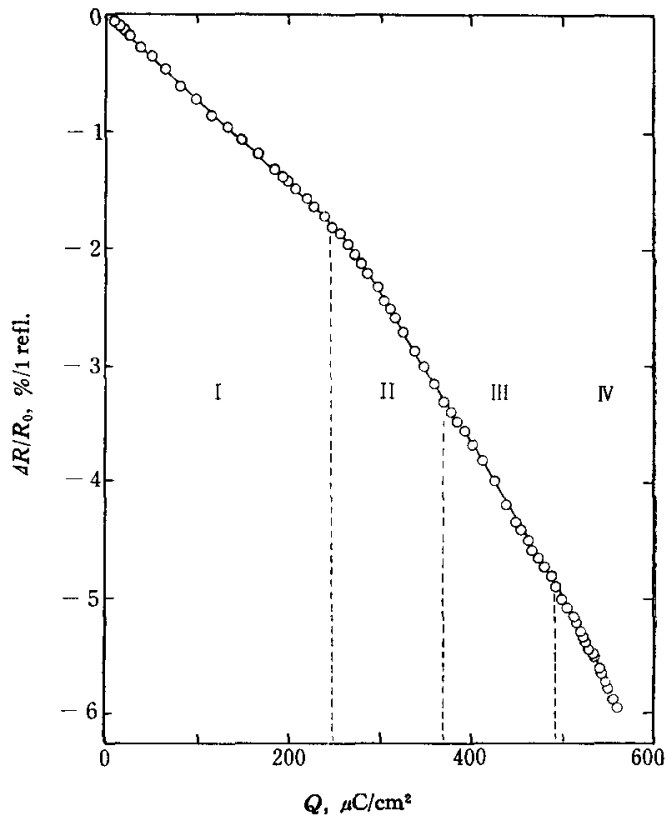

四 $201 M \mathrm{HClO}_{4}$ から $\mathrm{Au}$ 上K吸着した $\mathrm{Pb}_{\mathrm{ad}}$ に関する吸着量 $(Q)$ と $\Delta R / R_{0}$ との関係 $\left[\mathrm{Pb}^{2+}\right]=1 \times 10^{-8} M$

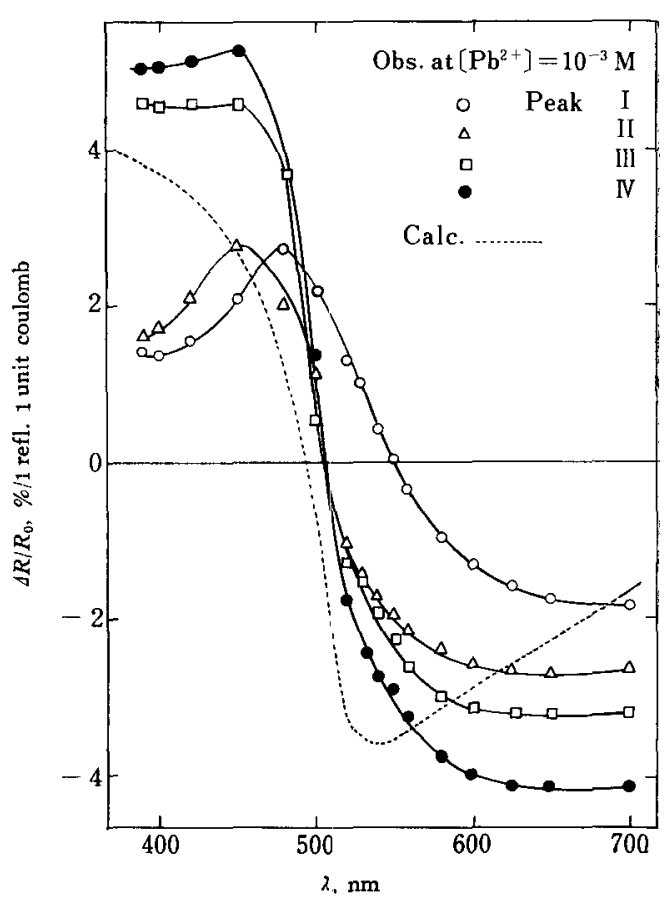

困 $21 \mathrm{~Pb}_{\mathrm{ad}}$ に基らく $\Delta R / R_{0}$ の波長体存性の実測（実 線) 々竐算 (点線) 曲線. 図中の 4 本の曲線は 因 19 の各ビーク領域に対応主る。 
を集めている、 $\mathrm{M}^{\mathrm{n}+}$ が $\mathrm{M}$ となって析出する可逆電位 よりも正電位で $\mathrm{M}_{\mathrm{ad}}$ が生成し， $\mathrm{M}_{\mathrm{ad}}$ に幾つかの異な る状態があることが指摘されている。これに関する直接 的知見が光学測定加えられる。図 19 に示寸よ5に $\mathrm{Au}$ 極表面上に $\mathrm{Pb}_{\mathrm{ad}}$ が析出するとき $i-E$ 曲線に 4 個 のピークがえられる。これに㳔応する $R / R_{0}-E$ 曲線は， 実線で示寸ように，各電流ピークに対応し大きな変化を 示寸.

電流値を積分してえられる $\mathrm{Pb}_{\mathrm{ad}}$ の量， $Q_{\mathrm{ad}}$ と $\Delta R /$ $R_{0}$ の関係恃図 20 に示寸ように直線的で (26) 式が成 立していることを示す、しかし傾斜がピークごとに異な っており各ピーク電位領域ご上に状態が異なっているこ とを示唆している。

さらに $\Delta R / R_{0}$ は図 19 にも示したように著しい波長 依存性を示寸. $\Delta R / R_{0}$ の波長依存性を各ピークごレにプ ロットした曲線を，(22）式により金属 $\mathrm{Au}$ 金属 $\mathrm{Pb}$ の光学定数を用いて計算した曲線 (点線) と比較したの が図 21 である.最も正電位側のピークに対応する $A R /$ $R_{0}$-ス 曲線が計算曲線から最もはなれているので，吸着 状態が金属 $\mathrm{Pb}$ と相当異なる上思われるしかしピーク 林終了のところで単原子層形成が完了したときには，す でに金属 $\mathrm{Pb}$ に相当近い性質となっていることがわかる. この手法は他の種々の金属吸湴系にも応用可能である.

\section{7 内部反射法の応用 ${ }^{12,22,8)}$}

すでに（21）式で示したように鏡面反射法と同様の適 用が可能である.しかし光が光学的に密な媒体から粗な 媒体にむかって入射するため，光の振動電場は，電解液 に相当の深さでしみこむ.このため，内部反射法の特長 はいわゆる搪散層 (diffusion layer) 中の不安定種の検 出と追跡行うときに威力を発揮する. 電解しつつ中間 体の生成消滅を調べることが Kuwana や長により精力 的比究された。

\section{8 電極表面内部の問面 ${ }^{(2) 6}$}

電極体自身の表面内部の荷電粒子（たとえば電子）密 度は，さらに媣いバルク相とは一般に異なっていること
が予想され，これ惊半導体においては空間電荷層として よく知られている. 荷電粒子の密度のちが、はをのちが いをもたらし，このため，この薄層の存在による反射率 のちがいが観測される．したがって電極体表面内部にも メスを入れることが可能である．以上述べたように光の 反射の利用は広い範囲にわたる。

紙面の都合で定量的記述を大分省略したが，今後も広 く用いられる可能性がある有力な手段と考えられる。

\section{文献}

1) “Symposia of the Faraday Soc., No. 4" (1970), 二0男:士光学 的手法の特集.

2) "Advances in Electrochemistry and Electrochemical Engineering", Vol. 9, (1973), Ed. P. Delahay \& C.W. Tobias, John Wiley \& Sons, New York, この巻には内部反射(Hansen), 鏡面反射 (McIntyre)，エリブソメトリー (Muller と Krigger) などに関する詳細な説明がり㭫右におくとよい。

3）高村勉, ポーラログラフィー19, 1 (1973), 繶面反射法の総説

4）化学総説，No. 7, “分子レヘルからみた界面の電気化学”，(1974）, (日本化学会編)，電極界面の本質 (前田)，老はじ光学的手法， 半導体，金属，アノート酸化膜，分散系，膜等の総説.

5) M. Born, E. Wolf, "Principles of Optics", 2nd Ed. (1964). McMillan, New York, 物理光学の名著.

6) A. B, Winterbottom, "Optical Studies of Metal Surfaces" Kgl. Norske Videnskabs Selskabs Skrifter, (1955), エリブソ メトリーの原理，手法.

7) B.E. Conway, "Techniques of Electrochemistry", Vol. 1, Chab. 5 (1972), Ed. E. Yeager, \& a. J. Salkind, WileyInterscience Inc., New York.

8) N. J. Harrick, "Internal Reflection Spectroscopy", (1967), Interscience, New York, 内部反射法を確立した著者の名著; T. Kuwana, Ber. Bunsengesellschaft Phys. Chem. 11, 858 (1974)，OTEの権威による内部反射法つ化学への店用に関する総祱。

9) J.D.E. McIntyre, Surf. Sci. 37, 658 (1973), 綕説.

10) T. Takamura, K. Takamura, W. Nippe, E. Yeager, J. Electrochem. Soc. 117, 626 (1970).

11) Y.C. Chin, M.A. Genshaw, J. Phys. Chem. 73, 3571 (1969).

12) N. Sato, K. Kudo, T. Noda, Electrochim. Acta 16, 1909 (1971).

13) J.O’M. Backris, A.K.N. Reddy, B. Rao, J. Electrochem. Soc. 113, 1133 (1966)

14) T. Takamura, K. Takamura, Y. Hayakawa, Denki Kagaku 41, 823 (1973).

T. Takamura, K. Takamura, F. Watanabe, Surf. Sci. 44, 93 (1974).

15) T. Takamura. K. Takamura, F. Watanabe, Electrochim. Acta 19, 933 (1974). 